\title{
A comparison of untreated and formaldehyde-treated barley distiller's solubles and rapeseed meal as protein supplements in dairy cows given grass silage ad libitum
}

\author{
PEKKA HUHTANEN, HANNELE KHALILI and MATTI NÄSI \\ Department of Animal Husbandry, University of Helsinki, \\ SF-00710 Helsinki, Finland
}

\begin{abstract}
Twenty Friesian cows in four pens were arranged in a $4 \times 4$ Latin square experiment with 4 wk experimental periods to evaluate the effects on feed intake, milk yield and milk composition of treating barley dried distiller's solubles (DDS) with a formaldehyde reagent, and to compare DDS with rapeseed meal as a protein supplement in dairy cows given a grass silage-based diet. The control diet $(C)$ consisted of grass silage ad libitum fed with 8.5 $\mathrm{kg} / \mathrm{d}$ of concentrate based on barley, oats and barley fibre $(250,250$ and $500 \mathrm{~g} / \mathrm{kg}$ dry matter (DM)). In three other diets $1.5 \mathrm{~kg} / \mathrm{d}$ of the basal concentrate was replaced with rapeseed meal (RSM) treated for reduced ruminal degradability, $1.5 \mathrm{~kg}$ of untreated DDS (UDDS) or 1.5 $\mathrm{kg}$ of DDS treated with formaldehyde reagent at the level of $15 \mathrm{l} / \mathrm{t}$ (TDDS).

On average, protein supplementation increased silage and total DM intake by approximately $0.5 \mathrm{~kg} / \mathrm{d}(\mathrm{P}>0.05)$. Milk yield $(\mathrm{P}<0.1)$, protein content $(\mathrm{P}<0.05)$ and protein yield $(\mathrm{P}<0.01)$ were likewise increased. Untreated DDS had no effect on milk yield or milk composition as compared with diet C. Treatment of DDS with formaldehyde reagent tended to increase milk and protein yield as compared with UDDS, and resulted in a milk yield similar to that obtained with the RSM supplement. Compared with RSM, the mean milk protein yield was lower $(\mathrm{P}<0.01)$ when the diet was supplemented with DDS. Live weight gain was higher $(\mathrm{P}<0.05)$ in cows receiving RSM diet than in cows receiving DDS diets. Calculation of energy balance showed that increased milk energy output in cows fed diets containing protein supplements was mediated mainly through increased energy intake.
\end{abstract}

Index words: barley distiller's solubles, formaldehyde treatment, rapeseed meal, silage intake, milk production

\section{Introduction}

Dairy cows have shown considerable response to feeding of supplementary protein with grass silage based diets (GORDON et al. 1981; ThOMAS and RAE 1988; ChAMBERLAIN $e t$ al. 1989). It would appear that both digestibility and intake of silage are increased by increasing the protein concentration in the supplement, and that the energy intake is therefore increased as well (OLDHAM 1984). According to a review by OLdHAM (1984), most 
responses to protein supplementation are mediated through increased energy supply. The reason for greater silage intake is thought to be improved fibre digestibility in the rumen (Oldham, 1984), but greater silage intake in response to abomasal infusion of protein (Chamberlain et al. 1989) suggests that intake responses can also be mediated via an increased supply of protein to the abomasum.

Rapeseed meal is the usual protein supplement in dairy cow concentrates in Finland. In several studies supplementation of grass silage and cereal grain diets with rapeseed meal has been shown to increase milk yield (SETÄLÄ et al. 1984; TUORI and SYRJÄLÄ-Qvist 1988; 1989, unpublished). At present some high protein by-products from integrated starch-ethanol production from barley are also available in reasonable amounts (NÄSI 1988). In an earlier study, feeding barley protein $(370 \mathrm{~g}$ crude protein (CP)/ $\mathrm{kg}$ dry matter (DM)) in replacement for soybean meal reduced $\mathrm{N}$ retention in young cattle (HUHTANEN et al. 1989). In a feeding experiment with growing bulls, rapeseed meal increased daily gain by $50 \mathrm{~g}$, whereas barley protein had no effect, when compared with diets based on forage and barley alone (ARONEN 1990). Similarly, increasing the CP content of the concentrate with dried distiller's solubles (DDS) had no effect on milk yield or milk composition in dairy cows given grass silage-based diet (ALA-SEPPÄLÃ et al. 1988). Inefficient protein utilization of these by-products may be related to their high ruminal degradability as indicated by the absence of response in duodenal nonammonia $\mathrm{N}$ flow to increasing dietary $\mathrm{CP}$ content through the inclusion of wet distiller's solubles in the diet (Huhtanen 1992). It seemed reasonable that the supply of undegraded protein from distiller's solubles might be increased if the protein were protected from ruminal degradation by treatment with formaldehyde reagent. Treatment in this way of barley, whose protein is also highly degradable in the rumen, has increased milk yield in dairy cows given grass silage-based diet (KASSEM et al. 1987). A feeding experi- ment was accordingly undertaken to study the effect of the treatment of DDS with formaldehyde reagent, and to compare DDS and rapeseed meal treated for reduced ruminal degradability as protein supplements for dairy cows given grass silage ad libitum.

\section{Material and methods}

\section{Animals and management}

Twenty Friesian cows were used. The cows had calved 62 days (SE 5.6) before the start of the experiment and on average were in their 4 th lactation. The average milk yield before the start of the experiment was $28.4 \mathrm{~kg}$ (SE 0.78 ). The animals were held in a loose-housing barn divided into four pens of five cows. The cows were grouped into five blocks on the basis of the pre-trial milk yield, calving date and number. Within each block they were allocated at random to the four pens. Grass silage was given ad libitum for each pen, and concentrates individually in the milking parlour twice daily. Drinking water was freely available.

\section{Feeds}

The silage was made of first cut timothy, meadow fescue and red clover sward. The grass was cut with a disc mower and harvested with a precision-chop forage harvester after a wilting period of about $4 \mathrm{~h}$. The grass was ensiled into a bunker silo of $250 \mathrm{t}$ capacity using a formic acid based additive applied at a level of 4-5 1/t. Rapeseed meal (RSM) was treated for reduced ruminal degradability (Öljynpuristamo Ltd., Helsinki). The basal concentrate consisted of barley, oats and barley fibre $(250,250$ and $500 \mathrm{~g} / \mathrm{kg})$. Barley fibre, the cell wall fraction of the barley endosperm, and DDS were obtained from an integrated starch-ethanol process. DDS was divided into two portions, one of which remained untreated and the other of which was treated with a formaldehyde-containing reagent ((formalin $410 \mathrm{~g} / \mathrm{kg}$, short-chain fatty acids $430 \mathrm{~g} / \mathrm{kg}$, lig- 
none sulphonate $75 \mathrm{~g} / \mathrm{kg}$ and urea + utropine stabilizer $75 \mathrm{~g} / \mathrm{kg}$ (European Patent Office, ANON. 1982)). The rate of application of the reagent was $15 \mathrm{l} / \mathrm{t}$. Barley and oats were crushed before use. All the diets were supplemented with $0.25 \mathrm{~kg} /$ day of a commercial mineral mixture to meet the animals' requirements.

\section{Design and treatments}

The experiment was conducted according to $4 \times 4$ Latin square design balanced with respect to residual effects so that each treatment was preceded by each of the other treatments. The control diet (diet C) comprised grass silage ad libitum and $8.5 \mathrm{~kg} /$ day of the basal concentrate on an air dry basis. In the three other diets $1.5 \mathrm{~kg}$ of the basal concentrate was replaced with RSM (diet RSM), untreated DDS (UDDS) or DDS treated with the formaldehyde reagent (TDDS).

Milk yield and concentrate intake were recorded individually daily. After milking, any concentrate refusals were removed and weighed. Weighed amounts of silage were offered twice daily in sufficient quantities to ensure that $50-100 \mathrm{~g} / \mathrm{kg}$ was refused. Silage refusals were weighed once daily at $14 \mathrm{~h}$.

Each experimental period lasted for 4 weeks, of which the first 2 weeks served as an adjustment period for the cows to adapt to the new diet. The results were based on the data from weeks 3 and 4 in each period. Live weights (LW) were recorded at biweekly intervals before the afternoon feeding on two consecutive days, or on three consecutive days if the difference between the two days exceeded 6 $\mathrm{kg}$. LW change was calculated as a linear regression of time and LW.

\section{Sampling and analyses}

Samples of silage were taken twice a week and analyzed for oven DM. The ingredients of the concentrate supplements were sampled once a week and analyzed for DM. The silage samples were bulked over one period and con- centrate ingredients over two periods to provide a sample for chemical analysis. The methods for the chemical analyses and calculation of the feeding values have been described by HuhtANEn et al. (1988). Samples of milk were taken at the last four milkings at the end of the 3rd and 4th week of each experimental period and analyzed for fat, protein and lactose by an infra-red milk analyzer.

\section{Calculation of results and statistical analyses}

Metabolizable energy (ME) requirements for maintenance and LW change were calculated according to the Ministry of Agriculture, Food and Fisheries (ANON. 1984a) and milk energy according to TYRREL and REID (1965). ME available for milk production was calculated as the difference between ME intake and the ME requirement for maintenance (ignoring the effect of LW change), or as the difference between ME intake and the ME requirement for maintenance and live weight change (including the effect of LW change). The efficiency of the utilization of ME for milk production was calculated as milk energy/ME available for milk production.

The data were subjected to the analyses of variance for Latin square experiments. In all the analyses the data from one pen in a single period were treated as an experimental unit (6 d.f. for the residual). The sum of squares of the treatment effect was further partitioned into single degrees of freedom using orthogonal contrasts (SOKAL and ROHLF 1981) for comparisons of diet $\mathrm{C}$ vs. protein supplements $\left(C_{1}\right)$, RSM vs. DDS $\left(C_{2}\right)$ and the effect of treatment of DDS $\left(\mathrm{C}_{3}\right)$.

\section{Results}

The chemical composition and estimated feeding values of the dietary ingredients are presented in Table 1. The silage used was well preserved with a low $\mathrm{pH}$ and satisfactory fermentation characteristics. The NDF content of the barley fibre was markedly higher than the corresponding value in our earlier experi- 
Table 1. Chemical composition $(\mathrm{g} / \mathrm{kg} \mathrm{DM})$ and estimated feeding values of the experimental feeds.

\begin{tabular}{|c|c|c|c|c|c|c|c|}
\hline & Silage $^{1}$ & Barley & Oats & $\begin{array}{c}\text { Barley } \\
\text { fibre }\end{array}$ & RSM & $\begin{array}{c}\text { Untreated } \\
\text { DDS }\end{array}$ & $\begin{array}{c}\text { Treated } \\
\text { DDS }\end{array}$ \\
\hline Dry matter $(\mathrm{g} / \mathrm{kg})$ & 210 & 872 & 868 & 896 & 881 & 928 & 925 \\
\hline \multicolumn{8}{|l|}{ In dry matter } \\
\hline Ash & 88 & 25 & 33 & 27 & 80 & 123 & 158 \\
\hline Crude protein & 142 & 115 & 117 & 138 & 323 & 303 & 339 \\
\hline Ether extract & 49 & 33 & 68 & 89 & 117 & 68 & 64 \\
\hline Crude fibre & 308 & 55 & 112 & 163 & 133 & 45 & 35 \\
\hline $\mathrm{NFE}^{2}$ & 413 & 772 & 670 & 583 & 348 & 461 & 404 \\
\hline $\mathrm{NDF}^{3}$ & 558 & 226 & 296 & 714 & 281 & - & - \\
\hline $\mathrm{ADF}^{4}$ & 329 & 56 & 128 & 202 & 178 & - & - \\
\hline $\mathrm{ADL}^{5}$ & 32 & 9 & 30 & 43 & 77 & - & - \\
\hline \multicolumn{8}{|l|}{ Feed values } \\
\hline $\mathrm{FU}^{6} / \mathrm{kg} \mathrm{DM}$ & 0.727 & & $1.051^{7}$ & & 1.071 & 1.015 & 0.995 \\
\hline $\mathrm{ME} \mathrm{MJ/kg} \mathrm{DM}$ & 10.2 & & $12.3^{7}$ & & 12.7 & 12.2 & 12.0 \\
\hline $\mathrm{DCP}^{8} \mathrm{~g} / \mathrm{kg} \mathrm{DM}$ & 99 & & $97^{7}$ & & 267 & 252 & 281 \\
\hline
\end{tabular}

I In silage: $\mathrm{pH} 3.85$; in dry matter $(\mathrm{g} / \mathrm{kg})$ : water soluble carbohydrates 17 , lactic acid 94 , acetic acid 25 , propionic acid 0.1 , butyric acid 0.5 ; in total nitrogen $(\mathrm{g} / \mathrm{kg})$ : ammonia $\mathrm{N} 55$, soluble $\mathrm{N} 524$

2 NFE $=$ nitrogen free extracts

${ }^{3} \mathrm{NDF}=$ neutral detergent fibre

${ }^{4} \mathrm{ADF}=$ acid detergent fibre

$5 \mathrm{ADL}=$ acid detergent lignin

${ }^{6} \mathrm{FU}=$ feed unit $=0.7 \mathrm{~kg}$ starch

7 Feed values for a mixture of barley, oats and barley fibre $(25: 25: 50)$

${ }^{8} \mathrm{DCP}=$ digestible crude protein

ments (Näsı 1988; Huhtanen et al. 1988). The differences between the protein supplements in CP content and estimated feeding values were small.

Feed intake data are summarized in Table 2. There was a trend indicating higher intakes of silage DM when protein supplements were included in the diet. As a result, the total intake of DM and calculated intakes of FU and ME showed a non-significant tendency to increase with protein supplements. No differences between the protein supplements were observed in their effect on feed intake. As expected, digestible crude protein (DCP) intake was higher $(\mathrm{P}<0.001)$ when protein supplements were included in the diet. The dietary CP concentration was $136,150,148$ and 151 $\mathrm{g} / \mathrm{kg}$ DM for diets C, RSM, UDDS and TDDS, respectively.

The yield and composition of milk and the yields of milk constituents for cows receiving the experimental diets are shown in Table 3. On average, protein supplementation tended
$(\mathrm{P}<0.1)$ to increase milk yield and reduce milk fat content as compared with the unsupplemented diet (C). Milk protein content and milk protein yield were significantly $(\mathrm{P}<0.05$; $\mathrm{P}<0.01$ ) higher for cows given protein supplements. Among the three protein supplements, the best response in milk protein yield was obtained with RSM; the difference between RSM and the mean value of the DDS diets was significant $(\mathrm{P}<0.01)$. As compared with the control diet, untreated DDS had no effect on milk yield or milk composition. The formaldehyde treatment of DDS resulted in a slightly higher milk yield $(0.45 \mathrm{~kg} / \mathrm{d}$; $\mathrm{P}$ $>0.1)$, protein yield $(19 \mathrm{~g} / \mathrm{d} ; \mathrm{P}<0.1)$ and FCM yield $(0.55 \mathrm{~kg} / \mathrm{d} ; \mathrm{P}<0.1)$ as compared with UDDS, and the values were very close to those in cows receiving the RSM supplement. LW gain was higher $(\mathrm{P}<0.05)$ in cows given RSM supplement than in those given DDS supplements.

The results for the calculation of the ME balance are shown in Table 4. Inclusion of 
Table 2. Feed intake (kg DM/d) and estimated nutrient consumption for cows given the four diets.

\begin{tabular}{|c|c|c|c|c|c|c|c|c|}
\hline & \multicolumn{4}{|c|}{ Diet } & \multirow[b]{2}{*}{ SEM } & \multicolumn{3}{|c|}{ Significance } \\
\hline & Control & RSM & UDDS & TDDS & & $\mathrm{C}_{1}$ & $\mathrm{C}_{2}$ & $\mathrm{C}_{3}$ \\
\hline Silage & 10.15 & 10.36 & 10.57 & 10.67 & 0.193 & NS & NS & NS \\
\hline Concentrate & 7.00 & 7.27 & 7.12 & 6.98 & - & - & - & - \\
\hline Total & 17.15 & 17.64 & 17.70 & 17.64 & 0.231 & NS & NS & NS \\
\hline \multicolumn{9}{|l|}{ Dry matter } \\
\hline $\mathrm{kg} / 100 \mathrm{~kg} \mathrm{LW}$ & 2.81 & 2.89 & 2.89 & 2.89 & 0.019 & NS & NS & NS \\
\hline $\mathrm{g} / \mathrm{kg} \mathrm{LW}^{0.75}$ & 139.6 & 143.5 & 143.6 & 143.5 & 1.89 & NS & NS & NS \\
\hline Net energy (FU/d) & 14.74 & 15.21 & 15.21 & 15.01 & 0.179 & NS & NS & NS \\
\hline $\mathrm{ME}(\mathrm{MJ} / \mathrm{d})$ & 190.6 & 196.5 & 196.1 & 195.0 & 1.77 & o & NS & NS \\
\hline DCP $(g / d)$ & 1676 & 1942 & 1942 & 1973 & 24 & $* * *$ & NS & NS \\
\hline
\end{tabular}

SEM = standard error of means

Significance: o $(\mathrm{P}<0.10),{ }^{*}(\mathrm{P}<0.05),{ }^{* *}(\mathrm{P}<0.01),{ }^{* * *}(\mathrm{P}<0.001)$

Table 3. Milk production, live weight and feed conversion for the cows given the four diets.

\begin{tabular}{|c|c|c|c|c|c|c|c|c|}
\hline & \multicolumn{4}{|c|}{ Diet } & \multirow[b]{2}{*}{ SEM } & \multicolumn{3}{|c|}{ Significance } \\
\hline & Control & RSM & UDDS & TDDS & & $\mathrm{C}_{1}$ & $\mathrm{C}_{2}$ & $\mathrm{C}_{3}$ \\
\hline Milk yield $(\mathrm{kg} / \mathrm{d})$ & 23.83 & 24.64 & 24.05 & 24.50 & 0.20 & o & NS & NS \\
\hline FCM yield $(\mathrm{kg} / \mathrm{d})$ & 24.12 & 24.45 & 23.84 & 24.39 & 0.19 & NS & NS & o \\
\hline \multicolumn{9}{|c|}{ Milk composition $(\mathrm{g} / \mathrm{kg})$} \\
\hline Fat & 41.1 & 39.7 & 39.7 & 40.0 & 0.50 & o & NS & NS \\
\hline Protein & 28.8 & 29.9 & 29.1 & 29.3 & 0.22 & * & o & NS \\
\hline Lactose & 49.5 & 49.1 & 49.4 & 49.6 & 0.22 & NS & NS & NS \\
\hline \multicolumn{9}{|l|}{ Yield (g/d) } \\
\hline Fat & 973 & 973 & 948 & 972 & 10.6 & NS & NS & NS \\
\hline Protein & 680 & 732 & 695 & 714 & 6.1 & $* *$ & $* *$ & o \\
\hline Lactose & 1181 & 1209 & 1188 & 1216 & 12.5 & NS & NS & NS \\
\hline \multicolumn{9}{|l|}{ Live weight } \\
\hline Mean $(\mathrm{kg})$ & 614 & 615 & 618 & 616 & 2.7 & NS & NS & NS \\
\hline Change $(\mathrm{kg} / \mathrm{d})$ & 0.37 & 0.35 & 0.13 & 0.23 & 0.076 & NS & $*$ & NS \\
\hline \multicolumn{9}{|l|}{ Feed conversion ${ }^{1}$} \\
\hline $\mathrm{FU} / \mathrm{kg} \mathrm{FCM}$ & 0.384 & 0.387 & 0.427 & 0.402 & 0.012 & NS & o & NS \\
\hline DCP g/kg FCM & 56.1 & 66.1 & 67.3 & 67.4 & 1.05 & $* * *$ & NS & NS \\
\hline
\end{tabular}

1 Corrected for maintenance (FU and DCP) and live weight change (FU)

For significance: see Table 2

Table 4. Calculated ME balance $(\mathrm{MJ} / \mathrm{d})$ and efficiency of the utilization of ME for milk production.

\begin{tabular}{|c|c|c|c|c|c|c|c|c|}
\hline & \multicolumn{4}{|c|}{ Diet } & \multirow[b]{2}{*}{ SEM } & \multicolumn{3}{|c|}{ Significance } \\
\hline & Control & RSM & UDDS & TDDS & & $\mathrm{C}_{1}$ & $\mathrm{C}_{2}$ & $\mathrm{C}_{3}$ \\
\hline ME intake & 190.6 & 196.5 & 196.1 & 195.0 & 1.77 & o & NS & NS \\
\hline ME from LW change & -12.6 & -15.9 & -5.3 & -8.5 & 5.98 & NS & $*$ & NS \\
\hline \multicolumn{9}{|l|}{ Energy output } \\
\hline Maintenance & 64.2 & 64.3 & 64.6 & 64.3 & 0.25 & NS & NS & NS \\
\hline Milk & 75.8 & 77.5 & 75.3 & 77.2 & 0.51 & NS & o & $*$ \\
\hline \multicolumn{9}{|l|}{ Efficiency } \\
\hline Including LW change & 0.672 & 0.671 & 0.600 & 0.640 & 0.021 & NS & o & NS \\
\hline Ignoring LW change & 0.607 & 0.592 & 0.575 & 0.594 & 0.013 & NS & NS & NS \\
\hline
\end{tabular}

For significance: see Table 2 
protein supplements in the diet increased daily ME intake by approximately $5 \mathrm{MJ} / \mathrm{d}$ $(\mathrm{P}<0.1)$. Milk energy output was $1.9 \mathrm{MJ} /$ day $(\mathrm{P}<0.05)$ higher in cows given treated DDS than in those given untreated DDS. Including the effect of LW change in calculations, the efficiency of transferring surplus energy into milk tended $(\mathrm{P}<0.1)$ to be higher with the RSM than the DDS supplements; when the effect of LW change was ignored this difference disappeared.

\section{Discussion}

\section{Effect of protein supplementation}

The main effect of increasing supplementary crude protein intake was an increase in silage DM intake, in agreement with the observations of MURPHY et al. (1985), HEIKKILÄ et al. (1987, unpublished), TUORI and SYRJÄLÄ-QvisT (1988, 1989, unpublished) in studies with RSM. In this study, the mean response to protein supplementation in feed intake, of $0.21 \mathrm{~kg}$ per $10 \mathrm{~g} / \mathrm{kg} \mathrm{DM}$ increase in dietary CP concentration, was close to the value of 0.19 reported by OLdHam (1984) in a review. Chamberlain et al. (1989) reported a corresponding response of $0.29 \mathrm{~kg}$ with high D-value silage plus barley based concentrate diets. The response to RSM supplementation in milk yield was smaller than has often been observed when protein supplements are included in grass silage based diets (THOMAs and RAE 1988; Chamberlain et al. 1989). Similar or slightly higher responses were found (Murphy et al. 1985; HeIKKILÄ et al. 1987, unpublished; TUORI and SyrJÄLÄ-QviST 1988; 1989, unpublished) when RSM was used to supplement the protein level in cereal grain based concentrates for cows given grass silage ad libitum. At $0.32 \mathrm{~kg} /$ day per $100 \mathrm{~g} /$ day increase in supplementary CP intake, the milk yield response in our study was higher than the mean response of $0.20 \mathrm{~kg}$ reported by Gordon et al. (1981) in a review of similar studies with soybean meal supplementation. This may be explained by the quite low level of protein supplementation and low CP content of the basal concentrate that we used. There is also considerable variation $(0-0.051$ $\mathrm{kg}$ milk per $\mathrm{g} / \mathrm{kg}$ ) in the response to increase in concentrate CP content (THOMAS and RAE 1988). The proportion and amount of RSM in the concentrate was within the optimal range found in the studies of TUORI and SyRJÄLÄ-QvisT (1988; 1989, unpublished), indicating that with high quality silage given ad libitum the response to RSM supplementation is fairly small.

The effect of RSM supplements on milk protein concentration has been varied; MuRPHY et al. (1985) reported a similar increase to us, whereas TUORI and SyRJÄLÄ-Qvist (1988; 1989, unpublished) found variable effects. With the effects of RSM on milk yield and protein content combined, the increase of in milk protein yield in our experiment was $7.6 \%$. Our findings are in agreement with the data quoted by GoRDON et al. (1981) and Chamberlain et al. (1989), which indicate that increases in protein intake generally result in small, but consistent depressions in milk fat content and increases in milk protein content.

The average effect of protein supplementation on calculated ME intake was 3.1 MJ/ $10 \mathrm{~g} / \mathrm{kg}$ increase in dietary CP content. Calculation of the energy balance shows that protein response to energy input was great enough to account for the total increase in milk production with all protein supplements. In contrast to our results, consistent increase in the efficiency of the utilization of ME in response to protein supplementation was reported by Chamberlain et al. (1989). Assuming a degradability coefficient of 0.8 for silage and barley $\mathrm{N}$, the control diet was calculated to be adequate to meet the requirements of both rumen degradable (RDN) and rumen undegradable N (UDN) (Agricultural Research Council; Anon. 1984b). 
Comparison of rapeseed meal and distiller's solubles

RSM and DDS supplements had similar effects on feed intake, so that the higher protein yield in the cows fed the RSM supplement must mainly reflect the greater postruminal supply of amino acids. The rapeseed meal used in the present study was protected from ruminal degradation (degdability $0.50-0.55$ ). However, the differences in the protein degradability of the RSM and DDS supplements cannot be estimated by nylon bag technique because of the very small particle size of DDS. Also, the quality of the RSM protein is better than that of DDS in terms of higher concentration of lysine and methionine. The significantly higher milk protein yield and the slightly higher fat and lactose yields with the RSM diet than the DDS diet (mean values) were mainly due to the lower yields obtained with untreated DDS. Lower live weight gain with the DDS diets is in agreement with our earlier observation (ALA-SEPPÃLÃ et al. 1988).

\section{Effect of treatment of DDS}

The absence of response to UDDS supplement in milk yield is in agreement with our previous study (ALA-SEPPÄLÄ et al. (1988), in which UDDS replaced either barley or barley fibre in the concentrate. This suggests that amino acids were not supplied in adequate amounts to meet the requirements of the cows. Increasing dietary CP content by feeding wet UDS in replacement for barley or barley fibre had no effect on the postruminal supply of non-ammonia nitrogen (HUHTANEN 1992) in cattle given grass silage-based diet.

The treatment of DDS with formaldehyde reagent tended to increase the yield of all milk components as compared with untreated DDS, which resulted in a significant increase in milk energy yield. The tendency for milk yield to increase with the treatment of DDS is consistent with the findings for cows given untreated and treated barley or oats (KASSEM et al. 1987; MARTIN and Thomas 1988). Feed intake was not affected by the treatment of DDS, and live weight gain was even slightly higher in cows fed TDDS, suggesting that the chemical treatment modified the nutrient supply, possibly by increasing the supply of amino acids. The slower rate of degradation (Huhtanen et al. 1985; KASSEm et al. 1987) and the increased duodenal protein flow (Van RAMHORST and THOMAS 1988) with treated than with untreated barley support this suggestion. The quality of undegraded DDS protein may not be ideal for high producing dairy cows because of the low contents of lysine and sulphur-containing amino acids (NÄsı 1989). Lysine and methionine may be the first limiting amino acids in dairy cows given grass silage based diets (Thomas and Chamberlain 1984). In growing cattle the treatment of barley with formaldehyde reagent did not, however, increase live weight gain (HuHTANEN et al. 1985). A trend towards lower efficiency in the utilization of ME and smaller live weight gain in cows given untreated DDS may suggest that crude protein was supplied in excess and more energy was required for synthesizing and excreting urea. The energy expenditure of excreting the extra crude protein supplied by untreated DDS would be $1.8 \mathrm{MJ} / \mathrm{d}$ (Oldham 1984).

We conclude that the utilization of barley distiller's solubles in dairy cows fed grass silage based diet can be improved by treatment with formaldehyde reagent. The production response was similar for cows fed RSM and TDDS supplements; the only benefit of RSM was higher live weight gain.

Acknowledgements. The financial support of Alko Ltd. and the technical assistance of Mrs Maija Tuomola and Mr Jorma Tossavainen and his staff are gratefully acknowledged. 


\section{References}

Ala-Seppālä, H., Huhtanen, P. \& Nāsi, M. 1988. Silage intake and milk production in cows given barley or barley fibre with or without distiller's solubles. J. Agric. Sci. Finl. 60: 723-733.

ANON. 1982. Additive composition of animal feedingstuffs. European Patent Application No. 0043202. European Patent Office.

ANON. 1984a. Energy Allowances and Feeding Systems for Ruminants. Reference Book 433. Ministry of Agriculture, Food and Fisheries.

ANON. 1984b. The Nutrient Requirements of Ruminant Livestock. Supplement 1. Agricultural Research Council. Commonwealth Agricultural Bureaux. 44 p. London.

Aronen, I. 1988. Barley protein feed as protein supplement for growing cattle. Acta Agric. Scand. 40: 297-307.

Chamberlain, D.G., Martin, P.A. \& Robertson, S. 1989. Optimizing compound feed use in dairy cows with high intakes of silage. Recent Advances in Animal Nutrition (Ed. W. Haresign \& D.J.A. Cole), pp. 175-193. Butterworths.

Gordon, F.J., Unsworth, E.F. \& Peoples, A.C. 1981. Protein supplementation of silage-based diets for milk production. 54th Annual Report, Agricultural Research Institute of Northern Ireland. pp. 13-23.

Huhtanen, P. 1992. The effects of barley vs. barley fibre with or without distiller's solubles on site and extent of nutrient digestion in cattle fed grass-silage-based diet. Anim. Feed Sci. Technol. (In press).

Huhtanen, P., NÄsı, M. \& Khalilı, H. 1989. By-products from integrated starch-ethanol production from barley in the diets of growing cattle. J. Agric. Sci. Finl. 61: $451-462$.

-, Ala-Seppälä, H \& NÄsi, M. 1988. Response of silage intake and milk production to replacement of barley by barley fibre derived from integrated starch-ethanol process. J. Agric. Sci. Finl. 60: 711-721.

-, Poutiainen, E. \& Mikkola, T. 1985. The effect of supplementation of grass silage with rapeseed meal or Gasol-treated barley on the performance of growing cattle. J. Agric. Sci. Finl. 57: 75-84.

Kassem, M.M., Thomas, P.C., Chamberlain, D.G. \& RoBertson, S. 1987. Silage intake and milk production in cows given barley supplements of reduced degradability. Grass Forage Sci. 42: 175-183.
Martin, P.A. \& Thomas, P.C. 1988. Dietary manipulation of the yield and composition of milk: Effects of dietary inclusions of barley and oats in untreated or formaldehyde-treated forms on milk fatty acid composition. J. Sci. Food Agric. 43: 145-154.

Murphy, J.J., Gleeson, P.A. \& Morgan, D.J. 1985. Evaluation of protein source in the concentrate on the performance of cows offered grass silage ad libitum. Ir. J. agric. Res. 24: 151-159.

NÄsı, M. 1988. Evaluation of barley feed fractions from integrated ethanol-starch production in the diets of ruminants. J. Agric. Sci. Finl. 60: 701-709.

- 1989. Barley feed fractions from integrated starchethanol process in the diets of pigs. J. Agric. Sci. Finl. 61: $441-450$.

Oldham, J.D. 1984. Protein-energy interrelationships in dairy cows. J. Dairy Sci. 67: 1090-1114.

Setãlä, J., Syrjälä-Qvist, L., Tuori, M., Poutiainen, E. \& RIIPINEN, U. 1984. Feeding of high producing dairy cows according to protein requirements in grass silage based diets. J. Scient. Agric. Soc. Finl. 56: 73-82.

SoKAl, R.R. \& RohlF, F.J. 1981. Biometry. Second Edition. 859 p. W.H. Freeman and Company, New York.

Thomas, C. \& RAE, R.C. 1988. Concentrate supplementation of silage for dairy cows. Nutrition and Lactation in the Dairy Cow (Ed. P.C. Garnsworthy), pp. 327-354. Butterworths.

Thomas, P.C. \& Chamberlain, D.G. 1984. Manipulation of milk composition to meet market need. Recent Advances in Animal Nutrition 1984 (Ed. W. Haresign \& D.J.A. Cole) pp. 219-243. Butterworths.

TUori, M. \& SYrJÄLÄ-Qvist L. 1988. The effect of rapeseed meal on the digestibility and protein utilization of silage and hay based diet. Polish-Finnish Seminar on 'Nutritive Value of Rapeseed Protein and other Plant Protein in Animal Nutrition'. Jablonna, December 1988. 3 p.

Tyrrel, H.F. \& ReID, J.T. 1965. Prediction of energy value of cow's milk. J. Dairy Sci. 48: 1215-1223.

Van Ramhorst, H. \& Thomas, P.C. 1988. Digestion in sheep of diets containing barley chemically treated to reduce its ruminal degradability. J. Sci. Food Agric. 42: $1-7$.

Ms received December 21, 1990 
Tärkkelysrankki, suojauskäsitelty tärkkelysrankki ja rypsirouhe valkuaisrehuna lypsylehmillä vapaalla säilörehuruokinnalla

\author{
Pekka Huhtanen, Hannele Khalili ja \\ Matti Näsi \\ Helsingin yliopisto, kotielaintieteen laitos, \\ 00710 Helsinki
}

Kokeessa selvitettiin integroidusta tărkkelys-etanoliprosessista saatavan tärkkelysrankin arvoa lypsylehmien valkuaisrehuna vapaalla säilörehuruokinnalla. Koe tehtiin $4 \times 4$ latinalaisena neliönä, jossa koejakson pituus oli 28 pv. Koe-eläimină oli $20 \mathrm{Fr}$-lehmaaă, jotka oli jaettu neljaaăn 5 lehmän osastoon. Koejäsenină olivat kontrolli (ei lisävalkuaista), käsittelemătön tärkkelysrankki, formaldehydiă, orgaanisia happoja ja lignosulfonaatteja sisăltăvăllă liuoksella suojauskäsitelty tärkkelysrankki sekă Öpex-käsitelty rypsirouhe. Kontrolliruokinnalla lehmät saivat $8.5 \mathrm{~kg} / \mathrm{pv}$ văkirehua, joka koostui ohrasta, kaurasta ja ohrarehusta $(250,250 \mathrm{ja} 500 \mathrm{~g} / \mathrm{kg})$. Koeruokinnoilla tăstă văkirehusta korvattiin $1.5 \mathrm{~kg} / \mathrm{pv}$ yllă mainituilla valkuaisrehuilla.

Lisăvalkuaista saaneet lehmăt sőivăt keskimaaărin 0.5 $\mathrm{kg} / \mathrm{pv}(\mathrm{P}>0.05)$ enemmän säilörehun kuiva-ainetta. Valkuaisrehun antaminen lisăsi maitotuotosta $(\mathrm{P}<0.1)$, maidon valkuaispitoisuutta $(\mathrm{P}<0.05)$ sekă valkuaistuotosta $(\mathrm{P}<0.01)$. Kăsittelemăttömăllă tärkkelysrankilla ei ollut vaikutusta maitotuotokseen tai maidon koostumukseen kontrolliin verrattuna. Tärkkelysrankin suojauskăsittely lisăsi maitotuotosta $0.45 \mathrm{~kg} / \mathrm{pv}(\mathrm{P}>0.1)$, valkuaistuotosta $19 \mathrm{~g} / \mathrm{pv}(\mathrm{P}<0.1)$ ja RKM-tuotosta $0.55 \mathrm{~kg} / \mathrm{pv}(\mathrm{P}<0.1)$ kăsittelemăttömaaăn rankkiin verrattuna, ja tuotokset olivat hieman pienempää valkuaistuotosta $(18 \mathrm{~g} / \mathrm{pv})$ lukuunottamatta samat kuin rypsirouhetta saaneilla lehmillä. Rypsirouheeseen verrattuna keskimäărăinen valkuaistuotos oli rankkiruokinnoilla pienempi $(\mathrm{P}<0.01)$. Elopainon lisăys oli rypsirouhetta saaneilla lehmillă suurempi $(\mathrm{P}<0.05)$ kuin tärkkelysrankkia saaneilla. Energiataselaskelmat osoittivat, ettă lisäăntynyt maidon energiatuotos lisăvalkuaista saaneilla lehmillă johtui pelkăstảăn lisăăntyneestä săilörehun syönnistä. 